\title{
HUBUNGAN ANTARA PERSEPSI TERHADAP POLA ASUH DEMOKRATIS AYAH DAN IBU DENGAN PERILAKU DISIPLIN REMAJA
}

\author{
Oleh: Istianah A. Rahman*
}

\begin{abstract}
This research is aimed to define the relationship between perception to democracy of the father and mother parenting style with adolescence's discipline behaviour. The method of data collecting that used is the scale of adolescence's perception to democracy of the father parenting style, the scale of adolescence's perception to democracy of the mother parenting style, and the scale of adolescence's discipline behaviour. All of the scales used by Likert Scale Model consists of four alternative responses. The data analysis is used by regression analysis technique. The result of the research indicated that: (1) there is significant and positive correlation between adolescence's perception to democracy of the father and mother parenting style with adolescence's discipline behaviour, (2) there is significant and positive correlation between adolescence's perception to democracy of the father parenting style with adolescence's discipline behaviour, (3) there is significant and positive correlation between adolescence's perception to democracy of the mother parenting style with adolescence's discipline behaviour. The conclusion of this research that the alternative hypothesis is accepted.
\end{abstract}

KEYWORDS: Persepsi, pola asuh demokratis, perilaku disiplin.

INDONESIA dalam menyikapi era globalisasi berusaha mempersiapkan generasi muda penerus bangsa, dengan mengupayakan sumber daya manusia yang handal dan berkualitas dalam intelektual, keterampilan, keimanan, kepribadian agar mampu berkompetisi dan memiliki daya saing yang tinggi. Untuk mewujudkan semua itu bekal utama yang sangat penting untuk dipersiapkan dan dimiliki oleh generasi muda adalah bekal disiplin, yang perlu dukungan dan partisipasi keluarga, sekolah dan masyarakat.

Masa remaja merupakan masa yang memiliki keunikan tersendiri dalam perjalanan hidup manusia. Menurut Monks dkk, rentang waktu

*Magister Sains dalam bidang Psikologi pada Program Pascasarjana UGM Yogyakarta ini adalah Dosen Fakultas Tarbiyah dan Keguruan UIN Alauddin Makassar dpk pada Universitas Negeri Makassar (UNM). 
remaja secara global berlangsung antara 12-21 tahun dengan pembagian sebagai berikut: a) 12-15 tahun (masa remaja awal); b) 15-18 tahun (masa remaja pertengahan); c) 18-21 tahun (masa remaja akhir). ${ }^{1}$ Dalam penelitian ini yang menjadi subjek penelitian adalah remaja awal yang berada pada rentang usia 12 sampai 15 tahun, di Indonesia remaja awal biasanya mereka yang tengah menempuh pendidikan di bangku SLTP. Oleh karena itu, peneliti menentukan subjek penelitian pada peserta didik kelas tujuh dan delapan SMP Nasima Semarang.

Fenomena perilaku remaja yang bersifat negatif banyak ditemukan di lingkungan masyarakat. Pemberitaan di media massa hampir setiap saat memuat dan menayangkan kasus-kasus mengenai perilaku negatif remaja. Berdasarkan data Badan Narkotika Nasional, sebagian besar korban penyalahgunaan narkoba berusia 15-25 tahun. ${ }^{2}$ Data lain mengungkap bahwa jumlah pengidap HIV di kalangan pengguna narkoba suntik berusia muda yakni dibawah 20 tahun, sangat merisaukan. ${ }^{3}$

Fenomena lain yang sangat akrab dengan keseharian, yakni sinetron yang tidak putus-putusnya mengangkat tema pelajar yang menggambarkan sisi-sisi kenakalan, urakan, pelanggaran etika, bahkan dalam percintaan sering terlalu seronok. Tema percintaan menjadi salah satu sebab banyaknya pergaulan bebas di kalangan remaja dan sedikit banyak berpengaruh terhadap perilaku remaja yang menontonnya. ${ }^{4}$

Terkait dengan fenomena "video game," tidak sedikit kaum ibu yang mengeluh karena remaja mereka telah keranjingan video game. Video game memang mengasyikkan dan bisa membuat orang kecanduan, membuat orang rela menghabiskan banyak waktu, orang jadi kurang produktif, kurang bersosialisasi, belum lagi sebagian judulnya yang dapat meningkatkan agresivitas. ${ }^{5}$

Fenomena-fenomena tersebut memperlihatkan bahwa perilaku negatif remaja terjadi akibat ketidak disiplinan remaja. Disiplin berasal dari kata latin "disciple" yang berarti mengajar atau memberi instruksi. ${ }^{6}$ Disiplin mengajar seseorang tentang dunia respon dengan satu cara sesuai harapan pada tindakan-tindakan bahwa perilaku tertentu selalu diikuti hukuman dan juga penghargaan atau imbalan. Disiplin juga membantu individu mengembangkan kontrol dan arah diri sehingga dia dapat membuat keputusan-keputusan yang bijaksana. ${ }^{7}$ Disiplin sebagai cara masyarakat mengajar remaja tingkah laku moral yang dihargai kelompok. Jelasnya disiplin adalah bagian dari perilaku positif yang idealnya dimiliki setiap orang, yang harus diajarkan sejak dini dan orangtualah yang bertanggung jawab untuk mengenalkan dan membentuk disiplin pada anak-anak mereka. 
Kian maraknya pelanggaran nilai etika dan moral remaja merupakan indikasi rendahnya disiplin diri, dan pemicu utamanya diduga adalah situasi dan kondisi keluarga yang negatif, di samping sebab-sebab lainnya seperti pergaulan kelompok sebaya, pengaruh media massa, lingkungan masyarakat, lingkungan keluarga, dan hilangnya sosok atau figur idealnya.

Realita di era global dewasa ini, tentang kompleksitas masalah kehidupan yang mengalami perubahan cepat sekali, dan anomali era global secara maknawi semakin meningkat untuk digandrungi oleh remaja misalnya minuman keras, narkoba, seks bebas, tawuran antar remaja dan sejenisnya. Berkaitan dengan itu, perubahan yang cepat mengharuskan adanya pelbagai upaya terhadap remaja agar mereka memiliki kemampuan untuk mengantisipasi, mengakomodasi, dan mewarnai arus globalisasi artinya tidak hanyut dan larut dalam arus global.

Keluarga merupakan bagian paling penting dalam jaringan sosial anak, sebab keluarga merupakan lingkungan pertama bagi anak dan orang pertama yang menanamkan dasar moral dan nilai-nilai yang ada. ${ }^{8}$ Hubungan anak dan orangtua merupakan hubungan yang lama dan berkesinambungan, sehingga diharapkan hubungan yang muncul adalah hubungan yang positif sehingga anak akan mempersepsikan hubungan tersebut secara positif pula.

Perilaku individu dapat diprediksi apabila diketahui bagaimana individu mempersepsikan situasi dan apa yang diharapkan. Perilaku seseorang ditentukan oleh persepsi mengenai diri mereka dan lingkungan sekitarnya, sehingga apa yang dilakukan merupakan cerminan dari lingkungan sekitarnya, dan persepsi dapat mempengaruhi perilaku, persepsi merupakan salah satu prediktor perilaku individu. ${ }^{9}$

Perilaku dapat diobservasi, dan dipelajari, baik langsung seperti tertawa, makan dan sebagainya, maupun tidak langsung seperti pikiran dan perasaan. Psikolog dapat membuat asumsi atau teori tentang perasaan, sikap, pikiran dan proses mental lainnya yang ada di belakang perilaku. Lingkungan mental internal dapat dipelajari sebagai manifestasi mereka dalam berperilaku. Oleh karena itu, penelitian ini fokus pada perilaku disiplin remaja di lingkungan SMP Nasima Semarang.

Banyak faktor dalam keluarga yang ikut berpengaruh dalam perkembangan kepribadian anak, salah satunya adalah pola asuh orangtua. ${ }^{10}$ Pola asuh orangtua merupakan suatu gambaran tentang sikap dan perilaku orangtua dan anak dalam berinteraksi, berkomunikasi selama mengadakan kegiatan pengasuhan. Baumrind menambahkan bahwa pola asuh merupakan kontrol orangtua (parental control). ${ }^{11}$ 
Pola asuh yang paling ideal yang dapat diterapkan orangtua (ayah dan ibu) dalam pengasuhan remaja adalah pola asuh demokratis. Cole dan Hall mengemukakan bahwa suasana terbuka dan kondusif yang ada pada pola asuh demokratis menyebabkan remaja menjadi lebih berkembang serta memiliki kemampuan menghadapi konflik yang terjadi dengan orang lain. ${ }^{12} \mathrm{Hal}$ tersebut dipertegas oleh Shapiro yang menjelaskan bahwa ayah dan ibu dengan pola asuh demokratis menjadikan anak tidak tergantung dan tidak berperilaku kekanak-kanakan, mendorong untuk berprestasi, anak menjadi percaya diri, mandiri, imajinatif, mudah beradaptasi, kreatif dan disukai banyak orang dan responsif. 13

Kerjasama ayah dan ibu dalam pengasuhan atau dikenal dengan istilah coparenting sangatlah penting, karena didalamnya terdapat sinergi kedua orangtua yakni orangtua dengan sisi positif masing-masing akan memberikan pengalaman kepada anak sehingga ada aspek-aspek yang berbeda pada diri anak yang berkembang. ${ }^{14}$

Disiplin merupakan aspek utama dan esensial pada pendidikan dalam keluarga, karena orangtua secara kodrati bertanggungjawab dalam meletakkan dasar-dasar fondasi disiplin kepada anak-anaknya. Perilaku disiplin sangatlah penting bagi kepribadian remaja, dan menurut peneliti pola asuh demokratis ayah dan ibu yang dipersepsi positif oleh remaja, efektif mendukung remaja dalam berperilaku disiplin. Berdasarkan uraian di atas maka peneliti mengadakan penelitian ini untuk menggambarkan persepsi remaja terhadap pola asuh demokratis orangtua secara terpisah yakni pengasuhan ayah dan ibu yang dihubungkan dengan perilaku disiplin remaja. Penelitian ini bertujuan untuk mengetahui hubungan antara persepsi remaja terhadap pola asuh demokratis ayah dan ibu dengan perilaku disiplin remaja. Dipilihnya SMP Nasima sebagai lokasi penelitian karena termasuk salah satu sekolah unggulan di wilayah Semarang yang dikelola Yayasan Pendidikan Islam (YPI) Nasima Semarang. YPI Nasima mengemban Visi: membimbing insan Indonesia yang berilmu dan berakhlak karimah, dan Misi: menyelenggarakan pendidikan berkualitas dan menciptakan lokomotif-lokomotif baru menuju Indonesia Raya.

\section{METODE}

Penelitian ini adalah penelitian kancah yang menggunakan dua pendekatan, yaitu pendekatan kuantitatif dengan menggunakan metode skala, dan pendekatan kualitatif dengan menggunakan metode observasi dan wawancara sebagai pengumpul data. ${ }^{15}$ Penelitian ini pada dasarnya menggunakan pendekatan kuantitatif. Subyeknya adalah peserta didik SMP Nasima Semarang, sebanyak enam kelas yakni: 7A, 7B, 7C, 8A, 8B, 
dan 8C, dengan jumlah total 133 orang (70 laki-laki dan 63 perempuan). Adapun subjek tryout adalah peserta didik kelas delapan SMP Muhammadiyah 4 Yogyakarta sebanyak 80 orang. Variabel terikat yang diukur adalah perilaku disiplin remaja. Instrumen yang digunakan adalah: 1) skala perilaku disiplin remaja, yang terdiri dari aspek: disiplin yang berhubungan dengan waktu; tempat; kesusilaan, norma-norma masyarakat dan agama, 2) skala persepsi remaja terhadap pola asuh demokratis ayah, dan 3) skala persepsi remaja terhadap pola asuh demokratis ibu, dua skala ini terdiri dari aspek kehangatan; peraturan dan disiplin; mengakui atau menghargai keberadaan anak; pemberian hadiah dan hukuman. Skalaskala tersebut disusun dengan menggunakan model skala Likert modifikasi. Adapun analisis datanya menggunakan teknik analisis regresi ganda, regresi sederhana, one-way anova, dan data diolah dengan memakai perhitungan statistik dan menggunakan jasa komputer Statistical Package for Social Science (SPSS) for Windows Versi 11.0.

\section{HASIL}

Berdasarkan hasil analisis data, dapat dikemukakan temuan penelitian berupa mempribadinya perilaku disiplin pada diri remaja yang disebabkan oleh kemampuan remaja mempersepsikan pola asuh demokratis ayah dan ibunya secara positif.

\section{Perilaku Disiplin Remaja}

Berdasarkan hasil analisis regresi linier berganda diperoleh koefisien regresi $R x 1.2 y$ sebesar 0,522 dengan $p=0,000$ ( $p<0,01$ ), hal ini menunjukkan bahwa terdapat hubungan yang sangat signifikan antara persepsi remaja terhadap pola asuh demokratis ayah dan ibu dengan perilaku disiplin remaja. Artinya, semakin positif remaja mempersepsikan pola asuh demokratis ayah dan ibunya, semakin positif pula perilaku disiplin remaja tersebut

Hasil analisis regresi linier diperoleh koefisien regresi Rx1y sebesar 0,515 dengan $\mathrm{p}=0,000(\mathrm{p}<0,01)$. Artinya ada hubungan positif yang sangat signifikan antara persepsi remaja terhadap pola asuh demokratis ayah dengan perilaku disiplin remaja.

Hasil analisis regresi linier, diperoleh koefisien regresi Rx2y sebesar 0,415 dengan $\mathrm{p}=0,000(\mathrm{p}<0,01)$. Artinya ada hubungan positif yang sangat signifikan antara persepsi remaja terhadap pola asuh demokratis ibu dengan perilaku disiplin remaja. 


\section{Hasil Temuan Tambahan}

Berdasarkan perhitungan one-way anova diperoleh temuan bahwa hasil pengujian perbedaan jenis kelamin terhadap: 1) perilaku disiplin remaja, diperoleh $F_{\text {beda }}=2,990$ dengan $p=0,086(p>0,05)$. Artinya tidak ada perbedaan perilaku disiplin antara remaja laki-laki dan perempuan, sebagaimana terlihat pada nilai meannya yaitu laki-laki $(147,50)$ dan perempuan $(151,65)$. 2) Persepsi remaja terhadap pola asuh demokratis ayah, diperoleh nilai $F_{\text {beda }}=0,006$ dengan $p=0,938(p>0,05)$. Artinya tidak ada perbedaan persepsi remaja terhadap pola asuh demokratis ayah antara laki-laki dan perempuan, nilai meannya yaitu laki-laki $(136,91)$ dan perempuan $(137,11)$. 3) Persepsi remaja terhadap pola asuh demokratis ibu, diperoleh nilai $\mathrm{F}_{\text {beda }}=2,689$ dengan $\mathrm{p}=0,103(\mathrm{p}>0,05)$. Artinya tidak ada perbedaan persepsi remaja terhadap pola asuh demokratis ibu antara lakilaki dan perempuan, nilai meannya yaitu laki-laki $(142,59)$ dan perempuan $(146,46)$.

\section{PEMBAHASAN}

Persepsi remaja terhadap pola asuh demokratis ayah dan ibu dapat mempengaruhi terbentuknya perilaku disiplin remaja. Penyebabnya adalah peran keluarga dapat memberikan dasar pembentukan sikap, watak, tingkah laku, moral dan pendidikan pada anak, yang semua itu mampu dipersepsi remaja secara positif, sehingga berdampak positif pula pada kualitas kepribadian remaja, dalam hal ini pada perilaku disiplinnya.

Disiplin adalah latihan untuk menumbuhkan kendali diri, karakter atau keteraturan, dan efisiensi. ${ }^{16}$ Menurut Bernhard disiplin merupakan latihan bukan pengkoreksian, bimbingan bukan hukuman, mengatur kondisi untuk belajar bukan hanya pembiasaan. ${ }^{17}$ Lebih lanjut Bernhard menyatakan bahwa tujuan disiplin diri adalah mengupayakan pengembangan minat anak dan mengembangkan anak menjadi manusia yang baik, yang akan menjadi sahabat, tetangga, dan warga Negara yang baik. ${ }^{18}$

Disiplin adalah merupakan pelaksanaan tata tertib keluarga yang pembentukannya dilakukan oleh orangtua dan ditujukan kepada anakanaknya, sedangkan yang dimaksud tertib dalam pelaksanaan tata tertib menurut Djaka dalam Pudjono adalah: a) jika segala-galanya terjadi pada waktunya, b) jika segala-galanya pada tempatnya, c) jika segala-galanya menurut aturan yang tertentu. ${ }^{19}$

Kesimpulannya, disiplin adalah suatu keadaan tertib dimana orangorang yang tergabung dalam suatu kelompok tunduk pada peraturanperaturan yang telah ditetapkan, dengan kesadaran. Disiplin adalah 
tindakan atau perbuatan yang berupa bimbingan kearah tertib, yaitu: 1) disiplin dalam hubungannya dengan waktu, (misalnya yang berhubungan dengan masalah: makan, tidur, belajar, bermain, bepergian, dan kegiatan keseharian lainnya); 2) disiplin yang ada hubungannya dengan tempat, (misalnya yang berhubungan dengan masalah: makan, tidur, belajar, bermain, meletakkan benda-benda pada tempatnya); 3) disiplin yang ada hubungannya dengan kesusilaan, norma-norma masyarakat dan agama, (misalnya yang berhubungan dengan masalah: pakaian dan cara berpakaian, orangtua, saudara, teman-teman dan orang lain, cara berbicara dan perbuatan lainnya, cara makan, meninggalkan rumah, ibadah, pekerjaan dan kebiasaan sehari-hari).

Menurut Gnagey dalam Shochib, bahwa disiplin diri dalam hal ini perilaku disiplin merupakan produk disiplin. Kepemilikan disiplin memerlukan proses belajar. ${ }^{20}$ Pada awal belajar perlu ada upaya orangtua. Hal ini dapat dilakukan dengan cara: 1) melatih, 2) membiasakan diri berperilaku sesuai dengan nilai-nilai berdasarkan acuan moral. Jika anak telah terlatih dan terbiasa berperilaku sesuai dengan nilai-nilai moral, maka 3) perlu adanya kontrol orangtua untuk mengembangkannya. Akhirnya dapat disimpulkan bahwa upaya orangtua dalam membantu anak untuk memiliki dan mengembangkan perilaku disiplin berlangsung melalui empat proses, yaitu: pengenalan, pemahaman, pengendapan, dan pempribadian nilai moral. Sehingga apa yang menjadi harapan bersama dapat teraih, yakni terwujudnya remaja yang berperilaku disiplin yaitu remaja yang memiliki keteraturan diri berdasarkan nilai agama, nilai budaya, aturan-aturan pergaulan, pandangan hidup, dan sikap hidup yang bermakna bagi dirinya sendiri, masyarakat, bangsa, dan negara. ${ }^{21}$

Hasil uji hipotesis yang menunjukkan adanya temuan penelitian bahwa terdapat hubungan yang sangat signifikan antara persepsi remaja terhadap pola asuh demokratis ayah dan ibu dengan perilaku disiplin remaja. Akhirnya penelitian ini membuktikan bahwa dalam mewujudkan kepemilikan perilaku disiplin pada diri remaja salah satu hal penting yang mendukungnya adalah diterapkannya pola asuh demokratis oleh orangtua dalam pengasuhan anak-anaknya. Hal ini dipersepsi remaja secara positif. Dalam penelitian ini proses persepsi yang dilakukan remaja terhadap pola asuh demokratis orangtuanya mempengaruhi proses terinternalisasinya perilaku disiplin dalam kepribadian remaja.

Hetherington dan Parke menjelaskan bahwa pola asuh ayah dan ibu diartikan sebagai suatu interaksi antara ayah dan ibu dengan dua dimensi perilaku. ${ }^{22}$ Dimensi pertama adalah hubungan emosional antara ayah dan ibu dengan anak. Menurut Monks dkk. Bahwa lingkungan keluarga yang 
sehat bagi psikis individu ditentukan oleh faktor kasih sayang, kepuasan, emosional, perasaan aman dan kehangatan yang diperoleh anak melalui pemberian perhatian, pengertian, dan kasih sayang ayah dan ibunya. ${ }^{23}$ Dimensi kedua adalah cara-cara ayah dan ibu mengontrol perilaku anaknya, kontrol yang dimaksud adalah disiplin. ${ }^{24}$ Disiplin mencakup tiga hal yaitu peraturan, hukuman, dan hadiah. ${ }^{25}$ Tujuan dari disiplin adalah memberitahukan kepada anak mana yang baik dan mana yang buruk dan mendorongnya berperilaku sesuai dengan standar yang ada.

Pendapat Radke yang dinyatakan oleh Mussen bahwa cara terbaik untuk mengetahui pola asuh orangtua adalah melalui penilaian atau persepsi anak terhadap kebiasaan-kebiasaan dan sikap orangtua dalam mengasuh dirinya yaitu sebagai individu yang mengasuh secara langsung. ${ }^{26}$ Selanjutnya pernyataan Johnson dan Medinnus sebagaimana dikutip oleh Walgito bahwa dalam hubungan orangtua dengan anak ada beberapa aspek yang dapat diteliti antara lain, bagaimana anak mempersepsikan orangtua, dan bagaimana orangtua menanamkan disiplin kepada anak-anaknya. ${ }^{27}$ Disiplin dalam hal ini disejajarkan dengan bimbingan, artinya suatu metode yang digunakan orangtua untuk memastikan kesediaan anak mentaati bimbingan yang diterimanya.

Hurlock menyatakan bahwa persepsi individu dapat memotivasi perilakunya lebih lanjut. Objek persepsi yang dinilai tidak menyenangkan maka perilakunya negatif, sebaliknya individu yang mempersepsikan suatu objek secara positif akan mengkondisikan individu secara psikologis sebagai motivasi untuk berperilaku positif. ${ }^{28} \mathrm{Hal}$ ini dipertegas oleh Lindgren dkk. bahwa pendekatan kognitif menyatakan, perilaku seseorang ditentukan oleh persepsi dan pemahaman mereka terhadap situasi yang dikaitkan dengan tujuan. ${ }^{29}$ Oleh karena itu, hubungan antara orangtuaanak yang menyenangkan akan menumbuhkan persepsi yang baik pada anak tentang orangtua mereka, yang dampaknya mewarnai perilaku positif remaja.

Hurlock, membagi pola asuh menjadi tiga, yaitu: 1) Pola asuh otoriter dengan ciri-ciri: sikap orangtua kaku, keras, menuntut anak untuk patuh kepada semua perintah dan kehendak orangtua, kontrol yang sangat ketat terhadap tingkah laku, kurang memberikan kepercayaan, sering memberikan hukuman fisik, jarang memberikan pujian dan hadiah apabila anak berhasil atau berprestasi; 2) pola asuh demokratis dengan ciri-ciri: sikap orangtua senantiasa bersikap hangat kepada anak, orangtua selalu melaksanakan peraturan dan disiplin yang dibuat bersama dengan anak, anak dituntut secara konsisten untuk mentaati peraturan-peraturan dan disiplin dengan baik, diberi kesempatan untuk mandiri, diakui keberadaannya, 
serta orangtua selalu memberikan alasan-alasan rasional dalam hal pemberian hadiah dan hukuman; 3) pola asuh permisif (serba boleh) dengan ciri-ciri: sikap orangtua yang memberikan kebebasan penuh pada anak, kurang adanya kontrol, kurangnya penanaman disiplin dan nilai-nilai pada anak, serta keinginan anak hampir selalu dipenuhi. ${ }^{30}$

Pola asuh dan hubungan dalam keluarga diyakini mempunyai peran yang kuat dalam membentuk perilaku bahkan hingga seorang individu mencapai usia dewasa. Pola asuh dimunculkan antara lain dalam bentuk disiplin, kontrol, pemberian perhatian dari orangtua. Pola asuh yang paling ideal yang dapat diterapkan ayah dan ibu dalam pengasuhan remaja adalah pola asuh demokratis. Pola asuh demokratis dapat didefinisikan sebagai pola pemeliharaan anak atau kendali orangtua terhadap anak dengan cara kesederajatan dan lebih mengutamakan kepentingan anak atau child centeredness. ${ }^{31}$ Menurut Ancok dalam Kurniawan bahwa lingkungan terbaik untuk perkembangan kepribadian anak adalah lingkungan keluarga yang kondusif, terbuka dan demokratis. ${ }^{32}$

Pola asuh demokratis yang menjadi fokus penelitian ini mengacu pada pendapat Hurlock. Menurutnya ada empat komponen yang menandai pola asuh demokratis yaitu: 1) kehangatan, yang ditandai dengan adanya pemberian perhatian penuh, kasih sayang, dan kesediaan untuk terus menerus memberikan arahan dan bimbingan kepada anak; 2) peraturan dan disiplin, yang ditandai dengan orangtua menetapkan batasan yang jelas tanpa kaku tentang kegiatan anak, menetapkan aturan secara konsisten, melatih kemandirian dan tanggungjawab; 3) mengakui dan menghargai keberadaan anak, yakni orangtua memahami kemampuan dan kelemahan anak, melibatkan anak dalam pengambilan keputusan, menanggapi pendapat dan komentar anak; 4) pemberian hadiah dan hukuman, yakni orangtua memberikan respon positif atau hadiah terhadap prestasi anak, sebaliknya memberikan hukuman terhadap kesalahan anak. $^{33}$

Temuan tentang idealnya penerapan pola asuh demokratis ayah dan ibu, didukung oleh temuan bahwa hubungan suami-isteri berpengaruh dalam cara orangtua mengasuh anak. Hubungan suami-isteri seharusnya merupakan hubungan yang saling melengkapi dan saling mendukung, ada kerjasama antara suami-isteri dalam mengurus rumah tangganya. Miller dalam penelitiannya juga menemukan bahwa penyesuaian diri dan penyesuaian pernikahan pasangan orangtua mempengaruhi kualitas cara pengasuhan mereka. Hal tersebut menunjukkan bahwa kematangan hubungan suami-isteri mempunyai pengaruh pada cara orangtua mengasuh anak. ${ }^{34}$ Oleh karena itu, penting dipahami bahwa kematangan kepribadian orangtua sangat esensial mewarnai pengasuhan coparenting. 
Pengasuhan coparenting menurut Andayani dan Koentjoro, adalah pengasuhan yang mempunyai gagasan kedua orangtua terlibat secara seimbang pada anak. Ayah dan ibu membentuk sinergi dalam mengasuh anak dengan memberikan keunikan masing-masing pribadi dalam interaksinya dengan anak. ${ }^{35}$ Oleh karena itu, kerjasama dalam pengasuhan (coparenting) adalah hal yang sangat penting.

Temuan penelitian ini juga relevan dengan penelitian Miller yang menemukan bahwa ketika ayah terlibat dalam pengasuhan anak dan menerapkan disiplin yang cukup tinggi akan mengurangi kecenderungan anak untuk berperilaku eksternalisasi seperti marah, bandel, dan berperilaku menyimpang, terutama pada masa sekolahnya. ${ }^{36}$ Pendekatan demokratis yang diterapkan dalam pola pengasuhan orangtua lebih disukai anak-anak seperti adanya saling pengertian, saling mendukung, tanpa ada negativitas di dalamnya. Hal ini dapat menjadikan anak berkembang dengan kualitas yang positif seperti kematangan emosi, sosial, dan intelektual.

Seorang ayah yang mempunyai tingkat trait expressiveness tinggi akan melibatkan dirinya dalam proses sosialisasi anak. Trait expressiveness adalah salah satu kepribadian yang pada awalnya digambarkan sebagai kualitas feminin, yang mengandung unsur-unsur kualitas seperti kelembutan, baik hati, dan peduli pada orang lain. ${ }^{37}$ Orang yang mempunyai sifat ini digambarkan cenderung mengarahkan orientasi pada hubungan (communal oriented) sehingga ia akan berusaha memberikan yang terbaik untuk menjaga keharmonisan hubungan dekat.

Penelitian yang dilakukan oleh Miller dkk. juga menemukan bahwa ibu adalah sosok yang mempunyai kemampuan afektif yang tinggi seperti: baik hati, lembut, dan penuh pengertian sehingga dapat berpengaruh pada segala aspek perkembangan anak, termasuk di dalamnya perilaku disiplin. ${ }^{38}$ Faktor pola asuh demokratis ibu ternyata memberikan peranan yang sangat berarti dalam proses tumbuh kembang remaja khususnya dalam proses pembentukan perilaku disiplin.

Uraian di atas telah memaparkan suatu temuan penelitian bahwa persepsi remaja terhadap pola asuh demokratis ayah dan ibunya telah memberikan pengaruh positif terhadap terbentuknya perilaku disiplin.

\section{KESIMPULAN}

Kesimpulan penelitian bahwa persepsi remaja dalam hal ini peserta didik SMP Nasima Semarang terhadap pola asuh demokratis ayah dan ibu berhubungan positif dan signifikan dengan perilaku disiplin. 


\section{SARAN}

Beberapa saran yang dapat dikemukakan berdasarkan hasil atau temuan penelitian ini, yaitu:

1. Bagi remaja awal, sejak dini diharapkan dukungan dan partisipasinya serta bersikap positif, pro aktif, dan terbuka atas segala upaya orangtua, sekolah dan masyarakat yang berusaha seoptimal mungkin memaksimalkan proses tumbuh kembang remaja khususnya dalam hal disiplin.

2. Bagi orangtua (ayah dan ibu), penting untuk menerapkan dan mengembangkan pola asuh demokratis dalam pengasuhan keluarga, hendaknya lebih fleksibel dan eklektis dalam menerapkan dan memberikan model pengasuhan dalam mendidik remaja. Idealnya ayah-ibu menjadi figur teladan yang senantiasa menerapkan budaya komunikatif dengan remaja.

3. Bagi peneliti selanjutnya, penelitian yang telah dilakukan ini hanya meneliti faktor pola asuh demokratis ayah dan ibu saja, masih banyak faktor lain yakni sebesar 56,3\%, baik faktor internal maupun faktor eksternal yang berpengaruh terhadap perilaku disiplin remaja dan belum terungkap dalam penelitian ini.

\section{CATATAN AKHIR:}

1. F. J. Monks, Knoers A. M. P., dan Haditono S. R., Psikologi Perkembangan Pengantar dalam Berbagai Bagiannya, Yogyakarta: Gadjah Mada University Press, 2001, h. 262.

2. Zainul Arifin, "Kampus, Pasar Potensial Narkoba", Kedaulatan Rakyat, 16 Septem-ber 2004, h. 4.

3. Mohammad Riyadi, "Merisaukan, Jumlah Pengidap HIV di Kalangan Pengguna Narkoba Pemula", Kompas, 24 Juli 2004, h. 2.

4. Makhfudz, Sinetron Remaja, Dorong Pergaulan Bebas, Kedaulatan Rakyat, 16 September 2004, h. 6.

5. Asmadin, Keranjingan "Video Game" Bikin Lupa Waktu, Kompas, 03 Oktober 2004, h. 4.

6. Elizabeth B. Hurlock, Adolescent Development. Tokyo: Mc-Hill, Kogakusha, Ltd, 1973, h. 206.

7. Elizabeth B. Hurlock, Adolescent Development, h. 207.

8. Elizabeth B. Hurlock, Child development (2 ${ }^{\text {nd }}$ ed). Singapore: McGraw-Hill, Inc, 1984, h. 198

9. H. C. Lindgren, An Introduction to Social Psychology, New Delhi: Wiley, 1974, h. 118.

10. Elizabeth B. Hurlock, Psikologi Perkembangan: Suatu Pendekatan Sepanjang Rentang Kehidupan, Jakarta: Erlangga, 1997, h. 231.

11. D. Baumrind, Current of Parental Authority, Journal Development Psychology/ Monographis, 1971, Vol.4, 91-103, h. 93. 
12. L. Cole, and Hall, I. N., Psychology of Adolescence, New York: Rinehart and Winston, Inc, 1970, h. 213.

13. L. Shapiro, Mengajarkan Emotional Intelligence pada anak, Terjemahan: Alex, T. W., Jakarta: Gramedia Pustaka Utama, 2001, h. 57.

14. Budi Andayani dan Koentjoro, Psikologi Keluarga, Peran Ayah Menuju Coparenting, Surabaya: CV Citra Media, 2004, h. 29.

15. Sumadi Suryabrata, Pengembangan Alat Ukur Psikologi, Yogyakarta: Andi Offset, 2000, h. 37.

16. Intisari, Kumpulan Artikel Psikologi Anak, Jakarta: Gramedia, 1999. h. 18.

17. K. S. Bernhard, Discipline and Child Guide, New York: McGraw-Hill Book Company Inc, 1964. h. 37.

18. K. S. Bernhard, Discipline and Child Guide, h. 39.

19. Mohammad Pudjono, "Perbedaan Persepsi Remaja terhadap Disiplin Orangtua", Laporan Penelitian (tidak diterbitkan), Yogyakarta: Fak. Psikologi UGM, 1986, h. 13.

20. Mohammad Shochib, Pola Asuh Orangtua untuk Membantu Anak Mengembangkan Disiplin Diri, Jakarta: PT Rineka Cipta, 1998, h. 68.

21. Mohammad Shochib, Pola Asuh Orangtua untuk Membantu Anak Mengembangkan Disiplin Diri, h. 73.

22. E. M. Hetherington dan R. D. Parke, Child Psychology (4th ed), New York: McGraw-Hill Book Company, 1999, h. 128.

23. F. J. Monks, Knoers A. M. P., dan Haditono S.R., Psikologi Perkembangan Pengantar dalam Berbagai Bagiannya, h. 283.

24. E. M. Hetherington dan R. D. Parke, Child Psychology, h. 128.

25. Elizabeth B. Hurlock, Developmental Psychology, New York: McGraw-Hill, Inc, 1978, h. 119.

26. P. H. Mussen, Conger J. J., Kagan J., dan Huston C. A., Perkembangan dan Kepriba-dian Anak, Jakarta: Arcan, 1989, h. 35.

27. Bimo Walgito, Pengantar Psikologi Umum, Edisi Revisi, Cet. Ke4. Jakarta: Andi Offset, 1994, h. 58.

28. Elizabeth B. Hurlock, Child development, h. 215.

29. H. C. Lindgren, Byrne D., Petrinovich L., Psychology: An Introduction to A Behavioural Science ( $2^{\text {nd }}$ ed). New York: John Wiley \& Sons, Inc, 1966, h. 39.

30. Elizabeth B. Hurlock, Developmental Psychology, h. 115.

31. Elizabeth B. Hurlock, Child development, h. 217.

32. Rahmat Kurniawan, "Hubungan Kedemokratisan Pola Asuh Ibu dengan Strategi Menghadapi Masalah," Skripsi (tidak diterbitkan), Yogyakarta: Fak. Psikologi UGM, 2000, h. 39

33. Elizabeth B. Hurlock, Developmental Psychology, h. 114.

34. Miller P. H., Theories of Developmental Psychology (3nd ed), New York: W. H. Freeman and Company, 1993, h. 211.

35. Budi Andayani dan Koentjoro, Psikologi Keluarga, Peran Ayah Menuju Coparenting, h. 37.

36. P. J. E. Miller, Cauglin dan Huston T., “Expressiveness and Marital Satisfaction: The Role of Idealization Processes", in Journal of Marriage and The Family, Vol. 65, 978-995, h. 983. 
37. P. J. E. Miller, Cauglin, dan Huston T., "Expressiveness and Marital Satisfaction: The Role of Idealization Processes", in Journal of Marriage and The Family, h. 986.

38. P. J. E. Miller, Cauglin, dan Huston T., "Expressiveness and Marital Satisfaction: The Role of Idealization Processes", in Journal of Marriage and The Family, h. 989.

\section{DAFTAR PUSTAKA}

Andayani, B. dan Koentjoro, Psikologi Keluarga, Peran Ayah Menuju Coparenting, Surabaya: CV Citra Media, 2004.

Arifin, Z., 16 September 2004, Kampus, Pasar Potensial Narkoba, Kedaulatan Rakyat.

Asmadin, 03 Oktober 2004, Keranjingan "Video Game" Bikin Lupa Waktu, Kompas.

Baumrind, D., Current of Parental Authority, Journal Development Psychology/Monographis, 1971, Vol. 4, 91-193.

Bernhard, K. S., Discipline and Child Guide, New York: McGraw-Hill Book Company Inc, 1964.

Cole, L. dan Hall, I. N., Psychology of Adolescence, New York: Rinehart and Winston, Inc, 1970.

Clark, N. P. dan Gray, L. B., Effect of Economic Resources on Marital Quality in Black Married Couples, Journal of Marriage and The Family, 1993, No.4, 727734.

Flouri, E. dan Buchanan A., The Role of Father Involvement in Children's Later Mental Health, Journal of Youth Adolescence, 2003, Vol.26, 63-78.

Hadi, S., Metodologi Research, Jilid II. Cet.XX. Yogyakarta: Andi Offset, 2000.

Hetherington, E. M. dan Parke, R. D., Child Psychology (4 ${ }^{\text {th }}$ ed), New York: McGraw - Hill Book Company, 1999.

Hurlock, E. B., Adolescent Development. Tokyo: Mc-Hill, Kogakusha, Ltd, 1973.

-----, Developmental Psychology, New York: McGraw-Hill, Inc, 1978. -, Child development (2nd ed). Singapore: McGraw-Hill, Inc, 1984.

------, Psikologi Perkembangan: Suatu Pendekatan Sepanjang Rentang Kehidupan, Jakarta: Erlangga, 1997.

Intisari, Kumpulan Artikel Psikologi Anak, Jakarta: Gramedia, 1999.

Riyadi, M., 24 Juli 2004 Merisaukan, Jumlah Pengidap HIV di kalangan Pengguna Narkoba Pemula, Kompas.

Lindgren, H. C., An Introduction to Social Psychology, New Delhi: Wiley, 1974.

Lindgren, H. C., Byrne, D., Petrinovich, L., Psychology: An Introduction to A Behavioural Science ( $2^{\text {nd }}$ ed). New York: John Wiley \& Sons, Inc, 1966.

Makhfudz, 16 September 2004, Sinetron Remaja, dorong Pergaulan Bebas, Kedaulatan Rakyat.

Miller, P. H., Theories of Developmental Psychology (3nd ed), New York: W.H. Freeman and Company, 1993.

Miller, P. J. E., Cauglin dan Huston, T., Expressiveness and Marital Satisfaction: The Role of Idealization Processes, Journal of Marriage and The Family, 2003, Vol. 65, 978-995. 
Monks, F. J., Knoers, A.M.P. \& Haditono, S.R, Psikologi Perkembangan Pengantar dalam berbagai Bagiannya, Yogyakarta: Gadjah Mada University Press, 2001.

Mussen, P. H., Conger, J.J., Kagan, J., dan Huston, C.A., Perkembangan dan Kepribadian Anak, 1989, Jakarta: Arcan.

Essentials of Child Development and Personality. New York: Harper and Row Publisher, 1994.

Pudjono, M., Perbedaan Persepsi Remaja terhadap Disiplin Orangtua, Laporan Penelitian (tidak diterbitkan), Yogyakarta: Fakultas Psikologi UGM, 1986.

Kurniawan, R., Hubungan Kedemokratisan Pola Asuh Ibu dengan Strategi Menghadapi Masalah, Skripsi (tidak diterbitkan), Yogyakarta: Fakultas Psikologi UGM, 2000.

Riyadi, M., 24 Juli 2004 Merisaukan, Jumlah Pengidap HIV di kalangan Pengguna Narkoba Pemula, Kompas.

Shapiro, L., Mengajarkan Emotional Intelligence pada anak, Terjemahan: Alex, T.W, Jakarta: Gramedia Pustaka Utama, 2001.

Shochib, M., Pola Asuh Orangtua untuk Membantu Anak Mengembangkan Disiplin Diri, Jakarta: PT Rineka Cipta, 1998.

Suryabrata, S., Pengembangan Alat Ukur Psikologi, Yogyakarta: Andi Offset, 2000.

Walgito, B., Pengantar Psikologi Umum, Edisi Revisi, Cet. Ke4. Jakarta: Andi Offset, 1994. 